Preprint: Moyson, S., Raaphorst, N., Groeneveld, S. \& Van de Walle, S. (2017). Organizational socialization in public administration research: A systematic review and directions for future research. Forthcoming in American Review of Public Administration.

\title{
Organizational socialization in public administration research: A systematic review and directions for future research
}

\begin{abstract}
Using the PRISMA approach, we conducted a systematic review of 58 public administration studies of organizational socialization. Organizational socialization is the process of mutual adaptation between an organization and its new members. Our findings demonstrate a growing but geographically disparate interest in this issue. Public administration studies contribute to this research area with novel insights into the determinants of organizational socialization and its effects on employees' public service motivation, Eurocrats' support of supranational institutions, person-organization fit and differences in the socialization of male and female public employees. The review also shows that the effects of organizational socialization on the homogenization of employees' attitudes should not be exaggerated, especially relative to other homogenizing factors such as attraction or selection effects. The reviewed articles are methodologically eclectic, with a recent but growing interest in longitudinal designs. There are also weaknesses in the operationalization of organizational socialization. We conclude with an agenda for future studies on organizational socialization in public administration research.
\end{abstract}

\section{Keywords}

Literature review; PRISMA; Organizational socialization; Socialization tactics; Proactive behaviors; Public service motivation; Person-organization fit; Supranational socialization. 


\section{Organizational socialization in public administration research: A systematic review and directions for future research}

\section{Introduction}

Positions within organizations are frequently held by newcomers. For example, new recruits may be hired, and people may be promoted or transferred from one organization to another. Newcomers adapt their identities, roles and preferences to their position in the new organization. Organizations, too, make efforts to integrate newcomers into organizational roles and norms. This process of adjustment between organizations and individuals is referred to as 'organizational socialization'. It is essential to understand how such socialization works, to know how public organizations prepare new employees for their jobs - especially when they have the possibility to exercise discretion - but also to explain why public employees may or may not support the organizational goals.

There are at least three challenges specific to public-sector organizations that raise the question of how their newcomers are trained and socialized. Firstly, as a result of budget cuts and public administration reforms, there is increasing pressure on public employees to respond to conflicting demands (Schott, van Kleef \& Noordegraaf, 2016). For example, public managers are asked to do more with less. Newcomers in the public sector are often given frontline tasks in which interactions with citizens play a key role (e.g., police officers, tax officials, or social workers). Street-level bureaucrats are required to enforce rule compliance while simultaneously promoting trust and co-operation in their relations with citizens (OECD, 2003). Furthermore, street-level bureaucrats are expected to be responsive to citizens' specific situations, but also to make decisions that are consistent over time and in line with those of their colleagues (Piore, 2011; Rutz et al., 2015). Contemporary work contexts in which public officials operate allow managerial control over decision making, without necessarily limiting their discretionary 
powers (Piore, 2011; Silbey, 2011). By reflective discussions with colleagues, it is held (Piore, 2011), public officials could deal with novel cases and adjust their decisions as to make them consistent. Such discussions can be facilitated by the socialization tactics implemented in public organizations (e.g., through trainings or integration processes) or by newcomers' behaviors in informal networks of colleagues.

Secondly, public agencies have less flexibility in using investments and other monetary incentives to attract new agents and foster their motivation. Hence, socialization programs become even more crucial because they allow transmitting organizational values and culture among newcomers and fostering their organizational commitment (Romzek, 1990).

Thirdly, public-sector employees are attracted to public organizations for specific motivations, such as their interest in policy-making, their compassion for others' needs or their loyalty to serve the public interest. However, as public officials' tenure increases, they may become less idealistic (Kjeldsen, 2014). Blau (1960) suggests that they experience a 'reality shock' as they encounter citizens-clients who do not appreciate their efforts, and even cheat and lie to them. In his own study, Blau (1960, p. 348) observed that 'this disillusioning experience might make a worker bitter and callous, or induce him to leave the job, and even those who did not have either of these extreme reactions tended to change their orientation to clients'. The study of organizational socialization could give original insights in how public employees' attitudes and motivations evolve over time, focusing on different socialization sites (e.g., not only the interactions with colleagues but also with citizens) and different phases (e.g., not only at the start of the job but also as tenure increases).

The purpose of this article is to take stock of existing academic knowledge of organizational socialization in public organizations by systematically reviewing Public Administration (PA) research on the topic. A first glance at studies on socialization within public organizations gives 
the impression that they are scattered through different contexts that do not necessarily 'speak' to each other. A systematic review on this topic could offer a synthesis of these studies and assess their specific contributions to the topic of organizational socialization in the public sector.

The article begins with a section on previous research on organizational socialization which concludes that PA studies are nearly absent from existing reviews on organizational socialization. We subsequently discuss the scope and methods of the review. Within the findings, we distinguish five streams of research and present their main insights. We also look at the ways of conceptualizing and operationalizing organizational socialization, as well as the methods of data collection and analysis. The article ends with several recommendations for future PA research on organizational socialization.

\section{Existing research on organizational socialization}

Previous research on organizational socialization has shown that it is associated with a variety of key organizational outcomes, such as performance, survival or work disruption and productivity, and individual outcomes, such as organizational commitment, job satisfaction, role innovation, role clarity, stress, etc. (e.g. Bauer et al., 2007). Like the outcomes of organizational socialization, its determinants (often called 'antecedents') can be identified at the organizational or individual level too. At the organizational level, socialization 'tactics' can be 'institutionalized' or 'individualized' (Jones, 1986; Van Maanen \& Schein, 1979). With institutionalized socialization, organizations invite newcomers to think and behave according to pre-established roles, thus encouraging them to follow very structured processes. In sharp contrast, organizations relying on individualized socialization integrate newcomers more by default than by design and invite them to be innovative and to actively invent their own role in 
their new organization. Some studies also specifically focus on the effects of formal training, mentorship or other network resources that are intentionally provided by the organization to its members with the hope of facilitating their socialization (e.g., Antonacopoulou \& Güttel, 2010; Cooper-Thomas \& Anderson, 2006).

On the individual level, research has documented a variety of characteristics related to identity, personality traits, values or beliefs that influence the socialization process and its outcomes. Newcomers' characteristics can influence their motivation and ability to collect and internalize new information about their work and the organization (see Ashforth, Sluss \& Harrison, 2007, pp. 41-43). Newcomers can also adopt proactive behaviors to integrate into an organization. Through these behaviors, they identify both people and information within the organization to help address uncertainties related to their new responsibilities (Ashford \& Black, 1996). However, not all organizational members are equally proactive: proactivity depends on individual differences, such as in self-efficacy or goal orientation, but also contextual factors, such as the organizational culture or the managerial support (Crant, 2000).

To connect antecedents to outcomes, socialization research most often refers to theories of learning and uncertainty reduction (Saks \& Ashforth, 1997). Socialization antecedents, including individual proactive behaviors or organizational socialization tactics, are viewed as factors that allow an organization's members to obtain or more easily manage new information and social knowledge. This knowledge may include the content of their new job; strategies for interacting with their new colleagues and supervisors; or their new organization's culture, formal rules, informal norms and routines. Access to this knowledge as well as its acquisition and internalization by the newcomer influence the outcomes of organizational socialization (Klein \& Heuser, 2008). 
In organization research, several literature reviews have recently contributed to integrating existing studies on organizational socialization (Antonacopoulou \& Güttel, 2010, Ashford \& Nurmohamed, 2010; Ashforth, Sluss \& Harrison, 2007; Bauer, Bodnerr, Erdogan, Truxillo \& Tucker, 2007; Fang, Duffy \& Shaw, 2011; Cooper-Thomas \& Anderson, 2006; Griffin, Colella \& Goparaju, 2000; Klein \& Heuser, 2008; Klemme Larson \& Bell, 2013; Moreland \& Levine, 2001; Saks \& Gruman, 2011; Saks, Uggerslev \& Fassina, 2007). One of the main challenges within existing mainstream research on organizational socialization is that of becoming more 'localized' (Ashforth, Sluss, \& Harrison, 2007) or contextualized.

Despite the specificity of public organizations, it is striking to observe that PA studies and PA books, in those reviews, are rare or completely absent (e.g., Ashforth, Sluss, \& Harrison, 2007; Klemme Larson \& Bell, 2013) ${ }^{\mathrm{ii}}$. There are good reasons to think that general concepts designating socialization outcomes cannot be mechanically applied to public organizations. For example, in private organizations, performance can often be related to the profitability of newcomers' activities and integration whereas, in public organizations, objectives are more intangible, diverse and sometimes contradictory (e.g., implementing public policies and ensuring organizational efficiency). Similarly, depending on the organization and its activities, the content of general socialization antecedents such as training, mentorship or relations with colleagues may also be very different. For example, when training new recruits, private and public organizations are probably not required to put equal emphasis on accountability or the equitable treatment of their clients.

This systematic review on organizational socialization in public administration research complements earlier reviews focused on private-sector settings and highlights specific features of socialization in a public context. 


\section{Methods and scope of the review}

To conduct and report our review, we relied on the 'Preferred Reporting Items for Systematic Reviews and Meta-Analyses' (PRISMA) approach (Liberati et al., 2009). This approach provides the steps that should be followed to conduct a review, as well as a checklist of 27 information items that should be provided to readers for ensuring the transparency of the review. Transparency allows readers to assess the strengths and weaknesses of the reported research as well as the quality of the review itself. Five items concern the administrative information that should be included in the title, abstract, and introduction of the review (e.g., rationale, objectives, and funding sources of the review). Twelve items concern the reporting of the methods (e.g., eligibility criteria of the reviewed studies, information sources, and search strategy within the sources). Finally, ten items are related to the results of the review and their discussion (e.g., results of individual studies, their synthesis, and potential limitations).

PRISMA was developed in the field of health care sciences (Liberati et al., 2009) but has already been successfully applied in PA research (e.g., De Vries, Bekkers \& Tummers, 2015; Voorberg, Bekkers \& Tummers, 2015). The innovativeness and quality of PRISMA, as an approach for conducting systematic literature reviews, result from its elaboration process relying on repeated enhancements based on deliberation among review experts. They are also related to the transparency of this approach, as well as its recognition by review authors and journal editors. PRISMA and its extensions are detailed on a dedicated website ${ }^{\mathrm{iii}}$.

We selected all articles from the 'Public Administration' subject area of the Web of Science ${ }^{\text {iv }}$ published between January 1970 and December 2015 in which the title, abstract or keywords contained at least one of the following keywords/expressions: 'Onboarding; Newcomer; New employee; New hire; New recruit; Staff induction; Socialization; Socialisation; Socialized; Socialised'v. To build this list of keywords, we used and extended the lists of keywords identified in existing reviews of mainstream research on organizational socialization. Those 
reviews were identified through a two-step process. First, different combinations of the following keywords were searched for in the title or abstract of journal articles indexed in the Web of Science: Organization(al), Socialization, Socialisation, Socialized, Literature, Review, and Meta Analysis. Second, a snowballing search was conducted on Google Scholar among the literature reviews citing or cited by the reviews found during the first step. We considered the period of 2000-2014. This process allowed us to identify twelve literature reviews on the topic of organizational socialization, marked with a ' + ' in the reference list. These reviews had been published in the fields of management, psychology and human resources.

The search resulted in an initial list containing 130 PA articles on organizational socialization. Then, two of the authors independently excluded all articles that lacked any insight into the process of adjustment between an organization and its members. The two lists were compared to build a consensual, final list of $58 \mathrm{PA}$ articles on organizational socialization. They are marked with $\mathrm{a}^{\text {'*' }}$ in the reference list. Fourteen are literature reviews or conceptual articles.

In this review, we focus on published journal articles. This can potentially lead to a publication bias if there is an indication that books reveal findings that differ from findings published in journals. However, our knowledge of the field indicates that only a small number of PA books on organizational socialization has been published (e.g., Oberfield, 2014). In addition, most of these books have been condensed or excerpted into articles published in the PA journals covered by our review (e.g., Oberfield, 2010, 2012, 2014). This suggests that this review has not been affected by publication bias.

We analyzed the 58 PA studies on organizational socialization using a common grid addressing the following questions: What is the focus of the article? Which socialization antecedents, processes and outcomes have been scrutinized? Finally, how has organizational socialization been operationalized and what have been the methods of data collection and analysis? With 
these questions, we aimed at identifying the main lines of PA research on organizational socialization in order to summarize their substantive findings as well as to pinpoint potential innovations. For example, some socialization tactics used by public organizations have been examined whereas knowledge is lacking on the effects of some other tactics. Similarly, some research methods allow to look at socialization processes in a way that other methods do not. If those methods are not represented in existing studies, their use in future research could bring new findings to light. Two of the authors coded the articles, each focusing on a part of the coding grid. For the ten first articles, they filled and compared the entire grid to ensure the reliability of the data. The results of the analysis are summarized in the Appendix (see Table 1). The online version of the appendix can be used to sort the articles (e.g., by publication year). Organizational socialization is a recent topic in PA research (see Figure 1). Prior to 1996, the number of articles related to organizational socialization was marginal (seven articles). Between 1995 and 2010, an average of ten articles was published every five years. Interest in the topic of organizational socialization has grown exponentially in recent years, with 22 articles published between 2011 and 2015. That said, with a total of only 58 articles, organizational socialization remains a niche topic in PA research.

[Figure 1 here]

A large group of 26 articles (45\%) on organizational socialization focuses on US or Canadian public organizations (see Figure 2). There is, also, a fast-growing body of research about socialization to supranational institutions representing seventeen (29\%) of the articles. Seven (12\%) studies concern (national-level) organizations within European countries. Other areas such as Asia, Oceania or South America are not well represented, while Africa is not 
represented at all. Only one international article compares organizations among different countries.

[Figure 2 here]

Finally, existing studies on organizational socialization concern a diverse set of governmental levels and sectors. In our sample, there are articles looking at newcomers in local, regional, national, supranational and international organizations, including central ministries or more independent regulatory institutions. Data are collected in various organizations such as police departments, welfare organizations, European institutions, embassies, regulators, municipalities, universities, etc.

\section{Five streams of research on organizational socialization}

The PA studies on organizational socialization may be sorted in five research streams according to their main focus. A first category of sixteen PA articles shares with mainstream research on organizational socialization an interest in its effect on the degree of 'fit' between newcomers and organizations; however, the PA articles focus on public-sector organizations. A second category of eighteen articles examines 'supranational socialization' within institutions such as the European Commission, Council, Parliament and various surrounding agencies. A third, smaller set of six studies focuses on the effect of organizational socialization on public service motivation. A fourth category of four studies looks at differences in the socialization of male and female public employees. The last group of fourteen studies is more heterogeneous. 
Fit studies examine whether selection, onboarding, training, mentoring or promotion practices, as well as job and organizational characteristics, allow newcomers to become effective members of organizations. In other words, person-organization fit is a possible outcome of the organizational socialization process. Many of the sixteen studies in this category rely on Van Maanen \& Schein's (1979) rather restrictive definition of organizational socialization as 'the process by which an individual acquires the social knowledge and skills necessary to assume an organizational role' (p. 211). However, in this section, we use the concept of 'fit' as an umbrella term for referring to all studies that look at the congruence between newcomers' expectations, values or behaviors and those of their organization, team or network.

Fit studies typically look at employees' levels of loyalty and commitment (Bhambri, 1972; Gossett, 2003; Gould-Williams et al., 2014; Jaskyte \& Lee, 2009), their intentions to quit (Baker \& Jennings, 2000; Gould-Williams, 2013; Selden \& Sowa, 2015), their job satisfaction (Bhambri, 1972; Gould-Williams et al., 2014), their competence (Bhambri, 1972; Hsiung \& Hsieh, 2003), and their social integration (Hsiung \& Hsieh, 2003), as well as the perceived ambiguity, clarity or meaningfulness of their roles and goals within the organization (Bright, 2010; Hsiung \& Hsieh, 2003; Jaskyte, 2005; Peng, Pandey \& Pandey, 2015). Other fit studies assess the 'benefits' of newcomers as perceived by their supervisors (Dougherty \& Van Gelder, 2015) or the congruence between the values of an organization and its members (Peng, Pandey \& Pandey, 2015). Finally, Hatmaker \& Park (2014) look at newcomers' networks with their colleagues. Those networks are not only an instrument to acquire relevant information: they also provide newcomers with friendship and social support. In this respect, Hatmaker \& Park (2014) view newcomers' networks as a fundamental, intermediary output of organizational socialization, i.e. influencing newcomers' fit with the organization. 
Fit studies also include conceptual articles on the role of mentoring practices (Bozeman \& Feeney, 2007) and social networks (Hatmaker, 2015) in organizational socialization, on the transition of practitioners towards managerial positions (Patti \& Austin, 1978), and on the socialization in volunteer groups (Haski-Leventhal \& Cnaan, 2009). Finally, Yankey and Coulton (1979) compared a conceptual model of public professionals' contribution to the achievement of organizational goals stressing the role of selection and socialization processes with a model emphasizing organizational processes, structures and evaluations of performance.

Organizational participation does not automatically elicit a better fit between newcomers and their organization. In fact, there are qualitative drivers and impediments to this process. In the field of social welfare administration, for example, Patti and Austin (1978) suggest that direct service practitioners lack anticipatory role information when they are asked to socialize to a new role of supervisor. They must also have, before assuming their new position, role-taking and role-making abilities to recognize and combine the various new tasks involved in their supervisory roles, such as setting objectives, leading a team, preventing and solving conflicts, controlling processes, etc. Similarly, Peng, Pandey and Pandey (2015) show that the centralization of decision-making authority hampers the socialization process in public organizations. In contrast, work autonomy, such as in non-profit organizations, facilitates this process. This gives them an advantage, compared to public organizations, in achieving individual-organizational value congruence.

Furthermore, organizational socialization is not always crucial to ensure person-organization fit. For example, provisional task groups of volunteers often work very efficiently in fulfilling a given objective (Haski-Leventhal \& Cnaan, 2009), despite a shorter organizational participation. In fact, organizational socialization of newcomers may even be a cause of divergence in work preferences, for example between older and younger employees (Bright, 2010). Finally, Hsiung and Hsieh (2003) demonstrate that, among newly hired nurses, job 
standardization decreases the need for specific socialization tactics as standardization is positively correlated with task mastery, role clarity, acculturation and social integration.

Hence, organizational socialization is nor a necessary factor nor a sufficient factor of personorganization fit: in fact, the effect of the organizational socialization process on personorganization fit is highly dependent on a variety of antecedents. For example, Hatmaker and colleagues (Hatmaker, 2015; Hatmaker \& Park, 2014; Hatmaker, Park \& Rethemeyer, 2014) show that new organizational members are not only socialized thanks to classical organizational tactics such as classroom training, mentoring, orientation sessions, etc. In addition to these formal activities, proactive behaviors and network resources that are made available by interacting with new colleagues serve to inform newcomers about how to become full members of the organization.

To sum up, organizational socialization does not mechanically lead to higher homogeneity among employees or to a stronger fit with their organization. PA research on organizational socialization shows a variety of antecedents that influence public-sector workers' socialization in terms of motivations, attitudes and practices.

\section{Supranational socialization}

Eighteen articles concern supranational socialization. While studies of person-organization fit examine whether newcomers become 'good' organizational members through organizational socialization processes, supranational socialization studies do not have this normative perspective. Rather, they look at the effect of participating in supranational institutions on the roles, identities, and beliefs of new 'Eurocrats', including European officials and State representatives. Eurocrats, this literature notices, learn about each other's beliefs and interests through their interactions. In addition, supranational socialization of Eurocrats influences their 
policy and political preferences. One key concern of this literature is to understand whether and why new Eurocrats serve European interests and values or continue to privilege interests and values of their country of origin.

Many supranational socialization studies rely on Checkel's (2005) definition of socialization as a process of 'inducting actors into the norms and rules of a given community' (p. 804). Saurugger (2013) asserts that socialization occurs 'when norms, worldviews, collective understandings are internalized, and subsequently are codified by a group of actors' (p. 894). Similarly, Kerremans (1996) views socialization as the process whereby 'the immediate participants in the policy-making process, from interest groups to bureaucrats and statesmen, begin to develop new perspectives, loyalties, and identifications as a result of their mutual interactions' (p. 232). The approach of these studies is constructivist and neo-institutionalist: their focus is on the effects of interactions among organizational members, combined with the effects of the formal and informal norms of organizations.

In addition to conceptual papers about European socialization (Beyers, 2010; Eberlein \& Radaelli, 2010; Kerremans, 1996; Niemann, 2004; Quaglia, De Francesco \& Radaelli, 2008; Saurugger, 2013), empirical papers examine the socializing effects of European institutions on Eurocrats' interests and values, as well as the impacts of those effects on supranational decisions and integration (Erbelein \& Radaelli, 2010; Smith, 2000; Suvarierol, 2011; Suvarierol, Bsuioc \& Groenleer, 2013; Benson-Rea \& Shore, 2012; Hooghe, 2011; Irondelle, 2003; Juncos \& Pomorska, 2011; McCarthy, 1997). A set of articles has a focus on seconded national officials (Trondal, Van Den Berg \& Suvarierol, 2008; Murdoch \& Geys, 2012).

Despite the importance of supranational socialization, the literature suggests that this constructivist process should not be exaggerated, especially when compared to more structural factors such as the Eurocrats' national affiliation of origin (Hooghe, 1999; Trondal, van den 
Berg \& Suvarierol, 2008). Quaglia, De Francesco and Radaelli (2008) suggest that Eurocrats are multifaceted. Often, they become European in values as a result of supranational socialization. At the same time, they remain attached to their national interests of origin and deal with this blend of values and interests in their daily life (see also Eberlein \& Radaelli, 2010; Murdoch \& Geys, 2012).

\section{Public service motivation}

Six studies look at the effect of organizational socialization on public service motivation (Kim et al., 2013; Perry, 1996) of public-sector employees (Davis, 2011; Kjeldsen, 2014; Kjeldsen \& Jacobsen, 2013; Perry, 1997; Vandenabeele, 2011; Waterhouse, French \& Puchala, 2014). While those studies do not especially use the concept of "organizational socialization", they assume that newcomers' public service motivation is influenced by their interactions with their supervisor, co-workers and citizens-clients over time.

The main message that emerges from this research is that pre-entry levels of public service motivation tend to decrease after organizational entry (e.g., Kjeldsen \& Jacobsen, 2013). However, the results are often mixed. For example, Davis (2011) shows that union membership increased commitment to public interest and self-sacrifice over time, but it did not influence attraction to the policy-making process among blue-collar workers in the fire and police departments of two large cities in the US Midwest. According to Perry (1997), 'professional socialization' of public servants is negatively related to their attraction to policy-making and positively associated with civic duty and self-sacrifice.

Decreases in public service motivation are theoretically attributed to post-entry discrepancies (or 'reality shocks': Kjeldsen, 2014) between reality and newcomers' pre-entry expectations towards their supervisor, co-workers and clients. However, those decreases are weaker among 
newcomers entering the public sector than among newcomers entering the private sector. In addition, the type of public service newcomers must deliver (in particular, service regulation versus production) acts as moderators on the negative effect of organizational entry (Kjeldsen \& Jacobsen, 2013).

Finally, several scholars have substantiated the effect of specific socialization antecedents on public service motivation. In the Flemish administration, Vandenabeele (2011) finds that organizational members develop higher levels of public service motivation when the organization promotes public values through its (other) employees. In Welsh local authorities, Gould-Williams et al. (2014) find a positive effect of 'high commitment human resources practices' and a negative effect of work overload on the development of employees' commitment to civic duty - a dimension of public service motivation. Hence, organizations making special efforts to foster levels of public service motivation among their employees are able to temper the effects of discrepancies between newcomers' expectations and reality.

To sum up, public service motivation tends to decrease among newcomers in public organizations, as a result of discrepancies between their expectations and the characteristics of their new organization/job. However, this decrease depends on the type of sector, the type of service, and - interestingly - the initiatives made by organization to temper it.

\section{Socialization of male versus female public employees}

Four studies look at the effect of divergences in the socialization process of male and female employees on their integration and promotion in public organizations but do not find any evidence of such effect. For example, Gidengil and Vengroff (2008) suggest that organizational socialization may be responsible for differences in women's access to managerial positions because their organizational participation convinces them, over time, that those positions are 
not desirable. However, they do not find any support for this hypothesis. York (1988) does not find any difference in the managerial styles of men and women among 39 direct service practitioners who became managers in six clinical agencies in North Carolina. To explain this result, however, he fails to demonstrate empirically that a minority of women who best meet the male requirements of managerial positions could have better access to administrative promotions as a result of their organizational socialization. In other words, the existing research does not validate the alternative hypothesis that socialization antecedents, processes and outcomes are different for male and female newcomers. This does not mean, however, that the null hypothesis - that they are similar - is definitively correct.

\section{Other studies}

The last set of fourteen studies is more heterogeneous. For example, Oberfield examines the effect of organizational socialization on police officers' rule-following attitudes (Oberfield, 2010), use of force (Oberfield, 2012), as well as 'service-oriented motivations' (e.g., 'keeping order in the streets') and 'self-interested motivations' (e.g., 'getting a respected job') (Oberfield, 2014). He finds that, despite organizational socialization processes, pre-entry attitudes are likely to remain key factors of post-entry attitudes. For example, Oberfield (2014) observes that officers' service-oriented and self-interested motivations change over time as a result of 'informal organizational influences' (e.g., interactions with other newcomers and with veterans), as well as 'formal organizational influences' (e.g., training) in the police department of a large US city. Most importantly, he notes that training is associated with an increase in service-oriented motivations. Similarly, Oberfield (2010) finds that organizational influences can affect new welfare caseworkers' and police officers' propensity to make rule-oriented or individual user-oriented decisions. However, Oberfield (2010, 2014) also shows that pre-entry 
motivations remain the strongest predictors of those motivations after two years of employment. Oberfield (2012) finds similar results regarding new officers' propensity to use force ${ }^{\mathrm{vi}}$.

Several studies focus on various political outcomes of organizational socialization. For example, differences in the public spending preferences of male and female public employees are attributed to divergences in their respective organizational socialization processes, according to Dolan (2002) as well as Garand, Parkhurst and Seoud (1991). The latter also examine differences in voter turnout and political preferences among male and female employees. Collins (1985) observes that, in Irish local governments, public officials and political councilors follow different organizational socialization paths, which results in a mismatch between their respective interests. Jackson and Smith (1996) look at the effects of socialization on perceptions of corruption. While Australian citizens have 'black or white' perceptions of corruption, Jackson and Smith argue, politicians develop 'grey' perceptions because they are socialized over time to the 'functionalities' of corruption.

In Bianculli (2013)'s study, socialization contributed to the institutionalization of Brazilian regulators and shaped the professional identity of their members through the creation and integration of the Brazilian Association of Regulatory Agencies. Kim (2005) shows that locally employed staff members at the American Embassy in Seoul must cope with domestic antiAmerican sentiments. Nevertheless, he suggests, the staff internalizes its 'pride to work for a superpower government' as a result of a socialization process within the embassy.

\section{Theoretical impact of organizational socialization on the homogeneity of newcomers}

Organizational socialization is most often considered to be a process that induces homogeneity among employees of the same organization. In this respect, there are two categories of studies using socialization theories to understand employees' perceptions, attitudes and behaviors. A 
first category of studies compares organizational socialization to other theories explaining homogeneity. For example, Kjeldsen and Jacobsen (Kjeldsen, 2014; Kjeldsen \& Jacobsen, 2013) disentangle socialization and attraction/selection effects on levels of public service motivation. Similarly, Suvarierol (2011) notices a double homogenizing effect on EU Commission officials' identities and preferences, 'both before their time in the Commission in terms of self-selection and selection through international experience and during their time in the Commission in terms of organizational socialization through continuous daily exposure to the multinational environment of the Commission' (p. 24). Finally, Garand, Parkhurst and Seoud (1991) observe that homogeneity among US public officials in terms of political attitudes and policy preferences is due less to organizational socialization than to the selection criteria of the government, which lead to hiring a homogeneous staff. Overall, the impact of socialization, when compared to selection effects, should not be exaggerated.

A second category of studies compares socialization effects with theories accounting for heterogeneity in organizational members' attitudes and behaviors. Typical of this category are European socialization scholars, who examine cases in which organizational socialization overcomes differences among Eurocrats resulting from diverging national interests. This is also typical of scholars comparing the effects of organizational socialization and representative bureaucracy. In representative bureaucracy theory (Bradbury \& Kellough, 2011; Meier, 1993), 'passive representation' means that 'an organization includes individuals from specified groups, such as racial or ethnic minorities and women, within its ranks' (Bradbury \& Kellough, 2011, p. 158) while 'active representation' occurs when a bureaucrat 'presses for the interests and desires of those whom he is presumed to represent' (Mosher, p. 11; cited by Bradbury \& Kellough, 2011, p. 158). According to Wilkins and Williams (2008, 2009), new US policemen from racial minorities adhere to the values of the police department and practice racial profiling of citizens at least as much as their new colleagues (they 'become blue'). Similarly, Dolan 
(2002) shows that male and female public officials in the US Federal administration, much like members of the general public, differ in their spending priorities for various policy programs. However, 'women and men within each department are closer to one another in terms of their spending preferences than they are with colleagues of their own gender from other departments' (p. 371). Overall, organizational socialization effects seem to be stronger than representation effects.

\section{Research methods in the study of organizational socialization}

\section{Operationalization of organizational socialization}

Among the 58 studies reviewed in this article, organizational socialization may be considered a central concept in 47 of them ${ }^{\text {vii }}$. In a first category of fourteen articles, the process of socialization is scrutinized through the operationalization of one or more socialization antecedents (e.g., number or types of trainings) and one or more socialization outcomes (e.g., public service motivation or person-organization fit). Then, the relations between antecedents and outcomes are assessed.

In a second category of 33 articles, socialization is viewed as a factor explaining some outcomes (e.g., higher similarity among newcomers) or resulting from other independent variables (e.g., individual characteristics facilitating socialization). In eighteen of those articles, we did not find any clear statement on the qualitative or quantitative operationalization of organizational socialization. Most of the other articles use organizational affiliation as an indirect measure of organizational socialization on the basis of the following assumption: if individuals think and behave more similarly when they belong to the same organization, this means that some organizational socialization has occurred within this organization (e.g., Dolan, 2002; Kjeldsen \& Jacobsen, 2013). Some researchers weigh this operationalization of socialization according 
to the number of years of organizational affiliation, organizational socialization being higher when the individuals have had a longer tenure (e.g., Bright, 2010; Hooghe, 1999; Kjeldsen, 2014; Kjeldsen \& Jacobsen, 2013). Qualitative researchers such as McCarthy (1997), Smith (2000) Juncos and Pomorska (2011), McCarty (1997), Smith (2000) or Suvarierol (2011) look at the socialization of newcomers through the existence, frequency and content of their meetings within formal or informal groups.

\section{Data collection and analysis}

Among the 58 studies reviewed in this article, 44 studies are empirical. Among those 44 empirical studies, 16 studies rely on quantitative data; 12 studies use qualitative data; and 16 studies are based on both types of data. We only looked at data that were explicitly used in the analyses. For example, preliminary interviews used in preparing a survey were not considered.

Among the articles using quantitative data (with or without qualitative data), 25 studies are based on cross-sectional surveys conducted in one or more organizations. The surveys are mostly self-designed and adapted to specific research contexts. Dolan (2002)'s study is an isolated case relying on existing US election surveys. One study draws on 'naturally occurring' data, relying on a large sample of 'police stop forms' used by police officers (Wilkins \& Williams, 2009). Only two of the qualitative articles did not explicitly report interview data: Baker III \& Jennings (2000) mainly used documents to report on the organizational socialization of one individual while Gidengil \& Vengroff (2008) use documents and several descriptive statistics to make their arguments.

There has been a recent but growing interest in longitudinal designs of data collection and analysis. Indeed, the effect of organizational socialization on organizations and newcomers unfolds over time and depends on organizations' initial characteristics and newcomers' initial 
attitudes, which longitudinal designs allow to capture. Eight recent articles are based on quantitative longitudinal data (Hatmaker \& Park, 2014; Hatmaker, Park \& Rethemeyer, 2011; Kjeldsen, 2014; Kjeldsen \& Jacobsen, 2013; Oberfield, 2010, 2012, 2014; Waterhouse, French \& Puchala, 2014). The number of waves and the time span differ across studies. For example, Hatmaker and Park (2014) conducted six waves over four years whereas Oberfield (2010, 2012, 2014) conducted five waves over 24 months. Hatmaker and colleagues (Hatmaker \& Park, 2014; Hatmaker, Park \& Rethemeyer, 2011) use a longitudinal design involving several waves of interviews with the same interviewees. Finally, Suvarierol (2011) uses participant observations of 'cosmopolitanism practices' at the EU Commission.

\section{Conclusion and research agenda}

Organizational socialization studies examine the process of adjustment between new recruits and their organization. The objective of the present article was to review PA research about organizational socialization. In the existing reviews that have been conducted in organizational, psychological and human resources research on this topic, we observed that PA studies are nearly absent whereas specific expectations weigh on public-sector organizations' and employees' shoulders. We collected and analyzed 58 research articles following the PRISMA approach to systematic literature reviews (Liberati et al., 2009). We observed a growing interest in organizational socialization in PA research with, however, much geographical disparity. The PA scholars who looked at organizational socialization processes in public-sector organizations have contributed to the challenge of contextualization in organizational socialization research. Still, there are several avenues for future PA studies on organizational socialization. In the remainder of this conclusion, we look at several of those avenues with reference to the questions that guided our coding of the reviewed articles: What is the focus of the article? Which 
socialization antecedents have been scrutinized? Finally, how has organizational socialization been operationalized and what have been the methods of data collection and analysis?

First, we call for more research on socialization processes. Indeed, most of the scrutinized studies do not study socialization processes as such: they use them as a possible explanation for outcomes such as Eurocrats' political preferences or officials' public service motivation. Only fourteen of the reviewed studies look at the effect of specific antecedents on specific outcomes of organizational socialization. However, we learned that organizational socialization does not mechanically lead to higher homogeneity among newcomers and existing organizational members, which raises several questions. For example, are there some trainings that foster newcomers' attraction to public services (one dimension of public service motivation: Kim \& Vandenabeele, 2013) but diminish their compassion toward their citizens-clients (another dimension of public service motivation)? Are there specific organizational experiences of new Eurocrats that increase their commitment to European interests and/or diminish their sense of belonging to their home country? Answers to those questions are crucial to understanding and influencing socialization processes.

In a similar vein, PA research could expand its focus on socialization antecedents that are specific to the public sector. As said, the reviewed PA studies have contributed to the contextualization of organizational socialization research with their focus on socialization outcomes that are specific to the public sector (e.g., public service motivation of public officials or racial profiling by police officers). In contrast, the antecedents examined by those studies are rarely specific to public organizations even though these organizations have, we suspect, typical characteristics that are likely to influence the socialization of their newcomers. For example, does the specificity of hierarchical relationships between supervisors and public employees (Rainey, 2009) influence newcomers' socialization? How do new public professionals interacting with citizens learn to deal with the conflicting demands that weigh on them (Hupe 
\& Hill, 2007), such as satisfying individual demands, reducing costs or handling with political constraints? Finally, newcomers in the public sector are often given frontline tasks in which they hold a discretionary power towards citizens (Lipsky, 2010). How do newcomers learn to exercise this power? Do citizens behave differently with public-sector employees than with private-sector employees and, if so, how socialization processes can provide newcomers with the required information to deal with citizens' behaviors? This kind of research questions could be addressed to understand the specificity of public-sector socialization even more in the future.

Second, we need studies that do not only look at the processes allowing newcomers to become similar to existing organizational members, but also at those fostering their creativity and thus divergence. As noticed by Beyers (2010), many of the reviewed studies do not acknowledge that new public employees are not only role-takers but also role-makers. Consistent with this conceptualization, much empirical research focuses on the influence that organizations exert on newcomers' attitudes and behaviors. This perspective is functional - it assesses whether and how newcomers adapt their attitudes and behaviors to organizations' values and goals - and conservative - the hypothesis that newcomers are not only influenced by organizations but that they can also influence the latter receives, usually, less consideration.

However, in a context demanding more and more innovative public services (Osborne \& Brown, 2011), it would also be a fruitful endeavor to study how newcomers not only adopt organizational ways of thinking and acting, but also how they change the latter. How do such newcomers, who probably have different backgrounds than the more seasoned officials, work together with the latter and adjust to existing ways of working, while at the same time changing it? The study of organizational socialization within public-sector contexts could offer valuable insights in how public officials 'learn the ropes' in uncertain and ambiguous work environments and how they do not only reproduce existing values and practices, but also change it (e.g., Afsar, 2016). In other words, we argue that organizational socialization should be empirically explored 
as a process of mutual adaptation between public organizations and newcomers in which socialization outcomes can result from organizational influences as well as individual attitudes and behaviors.

Third, seven of the fourteen conceptual studies contained in our sample of articles are devoted to supranational socialization processes. This also means that nearly a half of the reviewed studies on supranational socialization are conceptual rather than empirical. Strong concepts and theories are crucial in the development of research. However, those statistics suggest a call for more empirical studies on supranational socialization processes.

Fourth, PA research could give more attention to informal socialization processes. Most studies look at formal practices or patterns of organizational socialization, such as organizational tactics, trainings, mentoring, etc. With the exception a few recent articles (e.g., Hatmaker, 2015; Hatmaker \& Park, 2014; Oberfield, 2014; Suvarierol, 2011), most existing studies do not look at informal socialization practices. How do teams integrate newcomers? How do senior members influence newcomers' perception of their mission and citizens-clients through meetings and discussions in front of the coffee machine? Do local managers take ad hoc initiatives to integrate newcomers? What is the influence of those informal socialization practices on newcomers' attitudes and behaviors? If organizations have the ambition to facilitate the integration of newcomers, a better understanding of those informal socialization practices is crucial.

Fifth, there is a need for more knowledge on the different types of socialization processes taking place in the different areas of the public sector. What are the systematic differences in socialization processes between police departments, social organizations or universities? In terms of levels, there can also be specificities in the socialization process of street-level bureaucrats, compared to middle- or top-level managers. Frontline public officials, for example, 
are confronted to dilemmas such as being consistent and treating everyone equally and, at the same time, being responsive to the specific cases (Rutz et al., 2015). Within the street-level bureaucracy literature, it is argued that in order to deal with work pressures and dilemmas, and to preserve the quality of professional judgment, officials involve colleagues or other peers in decision-making (Piore, 2011; Rutz et al., 2015). To what extent these considerations do or do not apply to public managers? Finally, organizational structures influence socialization processes (Saks \& Ashforth, 1997). For example, it could be hypothesized that socialization practices of central ministries and independent agencies are (or should be) different. All in all, socialization is still a niche topic, in PA research. For this reason, only a few number of studies have looked at diverse types of newcomers working at diverse levels in diverse types of public organizations. Future studies should reinforce our knowledge on the effects of variations in areas, levels or structures on organizational socialization processes.

Sixth, we call for methodological improvements. In particular, the conceptualization of organizational socialization is, too often, relatively weak in existing studies. As noted by Quaglia, De Francesco \& Radaelli (2008), a lack of clarity on the content of socialization prevents testing of the null hypothesis that socialization outcomes do not occur when socialization is absent. Furthermore, weaknesses in the operationalization of organizational socialization have also been observed. Often, organizational affiliation is assumed to be a fair indicator of socialization. In this case, similarities among employees of the same organization (relative to differences between employees of different organizations) are attributed to socialization processes. Admittedly, some researchers weigh this indicator of socialization with employees' length of service. However, without sufficient attention to employees' proactivity or their perceptions of socialization activities such as trainings, meetings or interactions, socialization effects cannot be disentangled from the effects of other homogenizing factors on employees' attitudes and behaviors such as selection or attraction effects. Finally, there is little 
explicit awareness that organizational socialization could be conceptualized and operationalized in different ways according to the theories used and the empirical contexts within which the research is done. This calls for more discussions among scholars within and between research streams on organizational socialization.

Furthermore, most of the PA studies on organizational socialization take the individual employee as their main unit of analysis: organizations, departments and teams are rarely compared to each other. This limitation makes it difficult to analyze the effects of socialization processes on organizational-level outcomes. Furthermore, considering that organizational socialization can be influenced by various collective-level factors such as socialization tactics or culture, we suspect that studies comparing multiple organizations in different geographical areas could provide surprising results, relative to existing research dominated by case studies conducted in North America and Europe. Finally, the growing number of studies based on longitudinal designs is promising, because those designs allow to disentangle the influence of pre-entry factors and post-entry factors (such as organizational socialization) on employees' attitudes and behaviors.

Changes taking place within public-sector organizations make organizational socialization research more relevant than ever. In the context of budget cuts and public administration reforms, there is increasing pressure on public employees to respond to conflicting demands (Schott, van Kleef, \& Noordegraaf, 2016). Hence, improving our understanding of the attitudes, skills, and organizational levers that allow newcomers to become effective, but also innovative and motivated organizational members, could bring relevant insights to the practitioners who have to deal with that pressure and those demands. 


\section{References}

Afsar, B. (2016). The impact of person-organization fit on innovative work behavior: The mediating effect of knowledge sharing behavior. International Journal of Health Care Quality Assurance, 29, 104-122.

+ Antonacopoulou, E., \& Güttel, W. (2010). Staff induction practices and organizational socialization: A review and extension of the debate. Society and Business Review, 5, 2247.

Ashford, S., \& Black, J.. (1996). Proactivity during organizational entry: The role of desire for control. Journal of Applied Psychology, 81, 199-214.

+ Ashford, S., \& Nurmohamed, S. (2012). From past to present and into the future: A hitchhiker's guide to the socialization literature. In C. Wanberg (Ed.), The Oxford handbook of organizational socialization (pp. 8-24). New York, NY: Oxford University Press.

+ Ashforth, B., Sluss, D., \& Harrison, S. (2007). Socialization in organizational contexts. International Review of Industrial and Organizational Psychology, 22, 1-70.

* Baker III, H., \& Jennings, K. (2000). Limitations in 'realistic recruiting' and subsequent socialization efforts: The case of Riddick Bowe and the United States Marine Corps. Public Personnel Management, 29, 367-377.

* Balle-Hansen, M., \& Lauridsen, J. (2004). The institutional context of market ideology: A comparative analysis of the values and perceptions of local government CEOs in 14 OECD countries. Public Administration, 82, 491-524. 
+ Bauer, T., Bodnerr, T., Erdogan, B., Truxillo, D., \& Tucker, J. (2007). Newcomer adjustment during organizational socialization: A meta-analytic review of antecedents, outcomes, and methods. Journal of Applied Psychology, 92, 707-721.

* Benson-Rea, M., \& Shore, C. (2012). Representing Europe: The emerging 'culture' of EU diplomacy. Public Administration, 90, 480-496.

* Beyers, J. (2010). Conceptual and methodological challenges in the study of European socialization. Journal of European Public Policy, 17, 909-920.

* Bhambhri, C. (1972). Socialization of IAS officers: Training and milieu (a self-evaluation). International Review of Administrative Sciences, 38, 61-71.

* Bhatta, G., \& Washington, S. (2003). 'Hands up': Mentoring in the New Zealand public service. Public Personnel Management, 32, 211-227.

* Bianculli, A. (2013). The Brazilian Association of Regulatory Agencies: Integrating levels, consolidating identities in the regulatory state in the south. Regulation \& Governance, 7, 547-559.

* Bozeman, B., \& Feeney, M. (2007). Toward a useful theory of mentoring: A conceptual analysis and critique. Administration \& Society, 39, 719-739.

Bradbury, M., \& Kellough, J. (2011). Representative bureaucracy: Assessing the evidence on active representation. American Review of Public Administration, 41, 157-167.

* Bright, L. (2010). Why age matters in the work preferences of public employees: A comparison of three age-related explanations. Public Personnel Management, 39, 1-14.

Checkel, J. (2005). International institutions and socialization in Europe: Introduction and framework. International Organization, 59, 801-826. 
* Collins, N. (1985). Councillor/officer relations in Irish local government: Alternative models. Public Administration, 63, 327-344.

+ Cooper-Thomas, H., \& Anderson, N. (2006). Organizational socialization: A new theoretical model and recommendations for future research and HRM practices in organizations. Journal of Managerial Psychology, 21, 492-516.

Crant, J. (2000). Proactive behavior in organizations. Journal of Management, 26, 435-462.

* Davis, R. (2011). Blue-collar public servants: How union membership influences public service motivation. American Review of Public Administration, 41, 705-723.

* Davis, R. (2013). Union commitment and stakeholder red tape: How union values shape perceptions of organizational rules. Review of Public Personnel Administration, 33, 365-383.

De Vries, H., Bekkers, V., \& Tummers, L. (2015). Innovation in the public sector: A systematic review and future research agenda. Public Administration, Early View.

* Dolan, J. (2002). Representative bureaucracy in the Federal Executive: Gender and spending priorities. Journal of Public Administration Research and Theory, 12, 353375.

* Dougherty, G., \& Van Gelder, M. (2015). Public Agency Hiring, Minimum Qualifications, and Experience. Review of Public Personnel Administration, 35, 169-192.

* Eberlein, B., \& Radaelli, C. (2010). Mechanisms of conflict management in EU regulatory policy. Public Administration, 29, 782-799.

+ Fang, R., Duffy, M., \& Shaw, J. (2011). The organizational socialization process: Review and development of social capital model. Journal of Management, 37, 127-152. 
* Garand, J., Parkhurst, C., \& Seoud, R. (1991). Bureaucrats, policy attitudes, and political behavior: Extension of the bureau voting model of government growth. Journal of Public Administration Research and Theory, 1, 177-212.

* Gidengil, E., \& Vengroff, R. (2008). Representative bureaucracy, tokenism and the glass ceiling: the case of women in Quebec municipal administration. Canadian Public Administration, 40, 457-480.

* Gossett, C. (2003). The changing face of Georgia's merit system: Results from an employee attitude survey in the Georgia Department of Juvenile Justice. Public Personnel Management, 32, 267-278.

* Gould-Williams, J., Bottomley, P., Redman, T., Snape, E., Bishop, D., Limpatnitgul, T., \& Mostafa, A. (2014). Civic duty and employee outcomes: Do high commitment human resource practices and work overload matter? Public Administration, 92, 937-953.

+ Griffin, A., Colella, A., \& Goparaju, S. (2000). Newcomer and organizational socialization tactics: An interactionist perspective. Human Resource Management Review, 10, 453474.

* Haski-Leventhal, D., \& Cnaan, R. (2009). Group processes and volunteering: using groups to enhance volunteerism. Administration in Social Work, 33, 61-80.

* Hatmaker, D. (2015). Bringing networks in: A model of organizational socialization in the public sector. Public Management Review, 17, 1146-1164.

* Hatmaker, D., \& Park, H. (2014). Who are all these people? Longitudinal changes in new employee social networks within a state agency. American Review of Public Administration, 44, 716-739. 
* Hatmaker, D., Park, H., \& Rethemeyer, R. (2011). Learning the ropes: Communities of practice and social networks in the public sector. International Public Management Journal, 14, 395-419.

* Hooghe, L. (1999). Consociationalists or Weberians? Top Commission officials on nationality. Governance, 12, 4397-4424.

* Hsiung, T., \& Hsieh, A. (2003). Newcomer socialization: The role of job standardization. Public Personnel Management, 32, 579-589.

Hupe, P. \& Hill, M. (2007). Street-level bureaucracy and public accountability. Public Administration, 85, 279-299.

* Irondelle, B. (2003). Europeanization without the European Union? French military reforms 1991- 96. Journal of European Public Policy, 10, 208-226.

* Jackson, M., \& Smith, R. (1996). Inside moves and outside views: An Australian case study of elite and public perceptions of political corruption. Governance, 9, 23-42.

* Jaskyte, K. (2005). The impact of organizational socialization tactics on role ambiguity and role conflict of newly hired social workers. Administration in Social Work, 29, 69-87.

* Jaskyte, K., \& Lee, M. (2009). Organizational commitment of social workers: An exploratory study. Administration in Social Work, 33, 227-241.

Jones, G. (1986). Socialization tactics, self-efficacy, and newcomers' adjustments to organizations. Academy of Management Journal, 29, 262-279.

* Juncos, A., \& Pomorska, K. (2011). Invisible and unaccountable? National representatives and Council officials in EU foreign policy. Journal of European Public Policy, 18, 1096-1114. 
* Kerremans, B. (1996). Do institutions make a difference? Non-institutionalism, neoinstitutionalism, and the logic of common decision-making in the European Union. Governance, 9, 217-240.

* Kim, L. (2005). Between a rock and a hard place: The impact of anti-Americanism on locally employed staff at the American embassy in Korea. Public Personnel Management, 34, 235-245.

Kim, S., Vandenabeele, W., Wright, B., Andersen, L., Cerase, F., Christensen, R., Desmarais, C., Koumenta, M., Leisink, P., Liu, B., Palidauskaite, J., Pedersen, L., Perry, J., Ritz, A., Taylor, J., De Vivo, P. (2013). Investigating the structure and meaning of public service motivation across populations: Developping an international instrument and addressing issues of measurement invariance. Journal of Public Administration Researhc and Theory, 23, 79-102.

* Kjeldsen, A. (2014). Dynamics of public service motivation: Attraction-selection and socialization in the production and regulation of social services. Public Administration Review, 74, 101-112.

* Kjeldsen, A., \& Jacobsen, C. (2013). Public service motivation and employment sector: Attraction or socialization? Journal of Public Administration Research and Theory, 23, 899-926.

+ Klein, H., \& Heuser, A. (2008). The learning of socialization content: A framework for researching orientation practices. Research in Personnel and Human Resources Management, 27, 279-336. 
+ Klemme Larson, R., \& Bell, A. (2013). Newcomer adjustment among recent college graduates: An integrative literature review. Human Resource Development Review, 12, 284-307.

Liberati, A., Altman, D., Tetzlaff, J., Mulrow, C., Goetzsche, P., Loannidis, J., Clarke, M., Devereaux, P., Kleijnen, J., \& Moher, D. (2009). The PRISMA statement for reporting systematic reviews and meta-analyses of studies that evaluate health care interventions: Explanation and elaboration. PLoS Med, 6, e1000100.

Lipsky, M. (2010). Street-level bureaucracy: Dilemmas of the individual in public services. New York, NY: Russel Sage Foundation.

* McCarthy, R. (1997). The Committee of the Regions: An advisory body's tortuous path to influence. Journal of European Public Policy, 4, 439-454.

Meier, K. (1993). Representative bureaucracy: A theoretical and empirical exposition. Research in Public Administration, 2, 1-35.

+ Moreland, R., \& Levine, J. (2001). Socialization in organizations and work groups. In M. Turner (Ed.), Groups at work. Theory and research (pp. 69-112). Mahwah, NJ: Lawrence Erlbaum Associates.

* Murdoch, Z., \& Geys, B. (2012). Instrumental calculation, cognitive role-playing, or both? Self-perceptions of seconded national experts in the European Commission. Journal of European Public Policy, 19, 1357-1376.

* Niemann, A. (2004). Between communicative action and strategic action: The Article 113 Committee and the negotiations on the WTO Basic Telecommunications Services Agreement. Journal of European Public Policy, 11, 379-407. 
* Oberfield, Z. (2010). Rule following and discretion at government's frontlines: Continuity and change during organization socialization. Journal of Public Administration Research and Theory, 20, 735-755.

* Oberfield, Z. (2012). Socialization and self-selection: How police officers develop their views about using force. Administration \& Society, 44, 702-730.

* Oberfield, Z. (2014). Motivation, change, and stability: Findings from an urban police department. American Review of Public Administration, 44, 210-232.

Oberfield, Z. (2014). Becoming bureaucrats: Socialization at the front lines of government services. Philadephia, PA: University of Pennsylvania Press.

OECD. (2003). Co-operative Compliance: A framework. From enhanced relationship to cooperative compliance. Paris, France: OECD Publishing.

Osborne, S., \& Brown, L. (2011). Innovation, public policy and public services delivery in th UK: The word that would be king? Public Administration, 89, 1335-1350.

* Patti, R., \& Austin, M. (1978). Socializing the direct service practitioner in the ways of supervisory management. Administration in Social Work, 1, 267-280.

* Peng, S., Pandey, S., \& Pandey, S. (2015). Is there a nonprofit advantage? Examining the impact of institutional context on individual-organizational value congruence. Public Administration Review, 75, 585-596.

Perry, J. (1996). Measuring public service motivation. An assessment of construct reliability and validity. Journal of Public Administration Research and Theory, 6, 5-22.

* Perry, J. (1997). Antecedents of public service motivation. Journal of Public Administration Research and Theory, 7, 181-197. 
Piore, M.J. (2011). Beyond markets: Sociology, street-level bureaucracy, and the management of the public sector. Regulation \& Governance, 5(1), 145-164.

Porath, C., \& Bateman, T. (2006). Self-regulation: From goal orientation to job performance. Journal of Applied Psychology, 91, 185-192.

* Quaglia, L., De Francesco, F., \& Radaelli, C. (2008). Committee governance and socialization in the European Union. Journal of European Public Policy, 15, 155-166.

Rainey, H. (2009). Understanding and managing public organizations. San Francisco, CA: Jossey-Bass.

* Rinfret, N., \& Lortie-Lussier, M. (1997). Le style de gestion des hommes et des femmes: convergence ou divergence? Canadian Public Administration, 40, 599-613.

Romzek, B. (1990). Employee investment and commitment: The ties that bind. Public Administration Review, 50, 374-382.

Rutz, S., Mathew, D., Robben, P., \& de Bont, A. (2015). Enhancing responsiveness and consistency: Comparing the collective use of discretion and discretionary room at inspectorates in England and the Netherlands. Regulation \& Governance, Early view.

Saks, A., \& Ashforth, B. (1997). Organizational socialization: Making sense of the past and present as a prologue for the future. Journal of Vocational Behavior, 51, 234-279.

+ Saks, A., \& Gruman, J. (2011). Organizational socialization and positive organizational behaviour: Implications for theory, research, and practice. Canadian Journal of Administrative Sciences / Revue Canadienne des Sciences de l'Administration, 28, 1426. 
+ Saks, A., Uggerslev, K., \& Fassina, N. (2007). Socialization tactics and newcomer adjustment: A meta-analytic review and test of a model. Journal of Vocational Behavior, 70, 413-446.

* Saurugger, S. (2013). Constructivism and public policy approaches in the EU: from ideas to power games. Journal of European Public Policy, 20, 888-906.

Schott, C., van Kleef, D., \& Noordegraaf, M. (2016). Confused professionals? Capacities to cope with pressures on professional work. Public Management Review, 18, 583-610.

* Selden, S., \& Sowa, J. (2015). Voluntary turnover in nonprofit human service organizations: The impact of high performance work practices. Human Service Organizations: Management, Leadership \& Governance, 39, 182-207.

Silbey, S. (2011). The sociological citizen: Pragmatic and relational regulation in law and organizations. Regulation \& Governance, 5, 1-13.

* Smith, M.E. (2000). Conforming to Europe: the domestic impact of EU foreign policy cooperation. Journal of European Public Policy, 7, 613-631.

* Smith, M.P. (1976). Barriers to Organizational Democracy in Public Administration. Administration \& Society, 8, 275-317.

* Suvarierol, S. (2011). Everyday cosmopolitanism in the European Commission. Journal of European Public Policy, 18, 181-200.

* Suvarierol, S., Bsuioc, M., \& Groenleer, M. (2013). Working for Europe? Socialization in the European Commission and agencies of the European Union. Public Administration, 91, 908-927. 
Taormina, R. (1997). Organizational socialization: A multidomain continuous process model. International Journal of Selection and Assessment, 5, 29-47.

Tipple, T., \& Wellman, J. (1991). Herbert Kaufman's forest ranger thirty years later: From simplicity and homogeneity to complexity and diversity. Public Administration Review, $51,421-428$.

* Trondal, J., Van Den Berg, C., \& Suvarierol, S. (2008). The Compound machinery of government: The case of seconded officials in the European Commission. Governance, $21,253-274$.

* Vandenabeele, W. (2011). Who wants to deliver public service? Do institutional antecedents of public service motivation provide an answer? Review of Public Personnel Administration, 31, 87-107.

Van Maanen, J., \& Schein, E. (1979). Toward a theory of organizational socialization. In B. Staw (Ed.), Research in organizational behavior (vol. 1, pp. 209-264). Greenwich, CT: JAI Press.

Voorberg, W., Bekkers, V., \& Tummers, L. (2015). A systematic review of co-creation and co-production: Embarking the social innovation journey. Public Management Review, $17,1333-1357$.

* Waterhouse, J., French, E., \& Puchala, N. (2014). The impact of socialisation on graduates' public service motivation: A mixed method study. Australian Journal of Public Administration, 73, 247-259.

* Wilkins, V., \& Williams, B. (2008). Black or blue: racial profiling and representative bureaucracy. Public Administration Review, 68, 654-664. 
* Wilkins, V., \& Williams, B. (2009). Representing blue: Representative bureaucracy and racial profiling in the Latino community. Administration \& Society, 40, 775-798.

* York, R. (1988). Sex-role stereotypes and the socialization of managers. Administration in Social Work, 12, 25-40. 
Figures

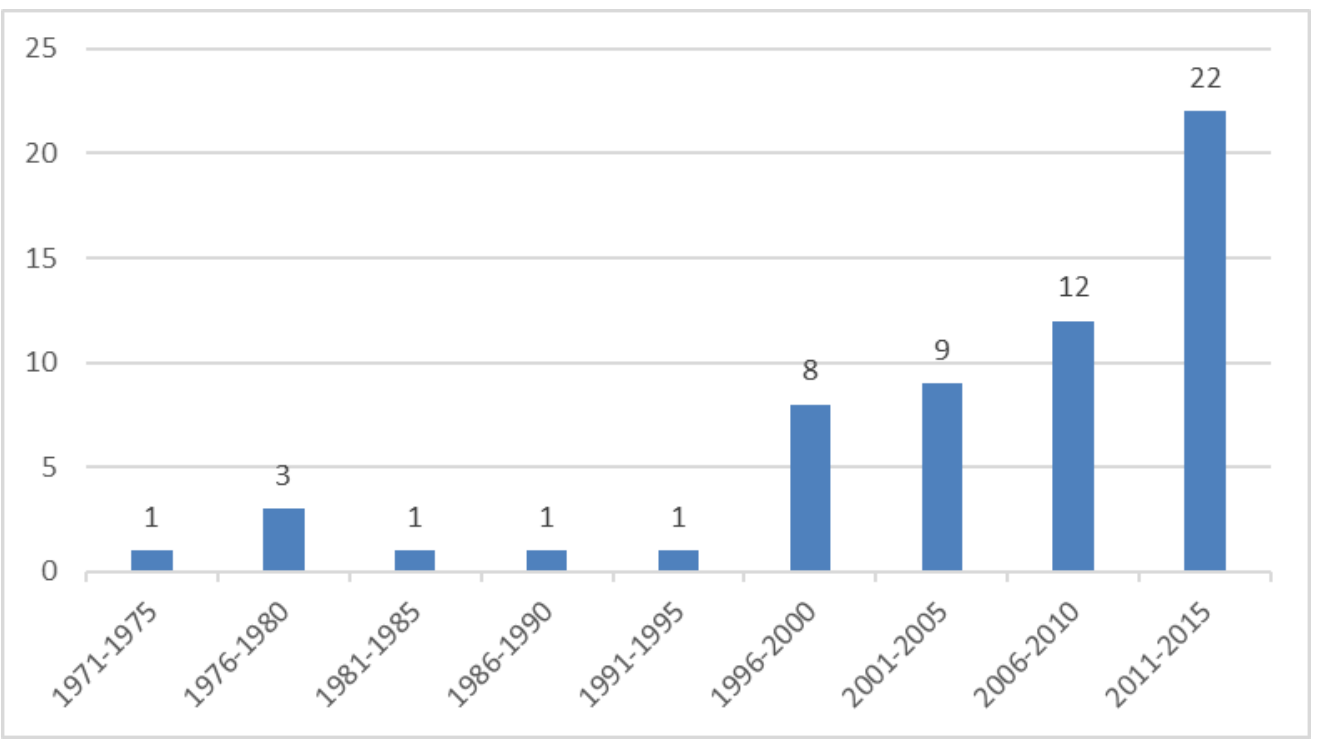

Figure 1. Number of articles over time $(n=58)$

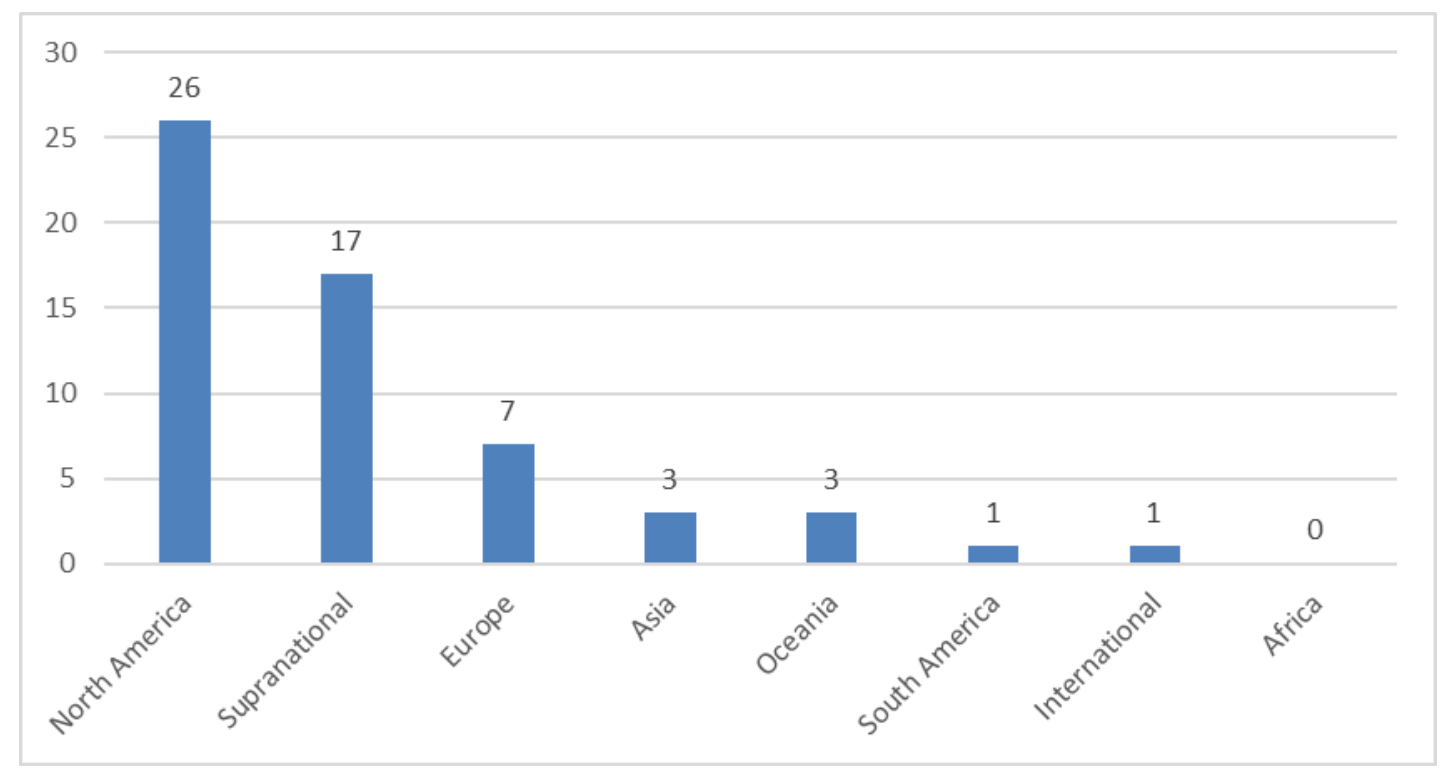

Figure 2. Number of articles per geographical area $(n=58)^{\text {viii }}$ 


\section{Appendix}

\begin{tabular}{|c|c|c|c|c|c|c|c|}
\hline Author(s) & Publication year & $\begin{array}{l}\text { Source } \\
\text { of the data }\end{array}$ & $\begin{array}{l}\text { Stream } \\
\text { of research }\end{array}$ & $\begin{array}{l}\text { Operationalization } \\
\text { of socialization }\end{array}$ & $\begin{array}{l}\text { Type } \\
\text { of the article }\end{array}$ & $\begin{array}{l}\text { Unit(s) } \\
\text { of analysis }\end{array}$ & $\begin{array}{l}\text { Type(s) } \\
\text { of data }\end{array}$ \\
\hline $\begin{array}{l}\text { Baker III, H. } \\
\text { Jennings, } \mathrm{K} \text {. }\end{array}$ & 2000 & North America & Person-organization fit & As a process & Empirical & Individuals & Qualitative \\
\hline Bhambhri, C. & 1972 & Asia & Person-organization fit & Concept not central & Empirical & Individuals & Quantitative \\
\hline $\begin{array}{l}\text { Bozeman, B., } \\
\text { Feeney, M. }\end{array}$ & 2007 & Europe & Person-Organization fit & Concept not central & Conceptual & & \\
\hline Bright, L & 2010 & North America & Person-Organization fit & Unclear & Empirical & Individuals & Qualitative \\
\hline $\begin{array}{l}\text { Dougherty, G. } \\
\text { Van Gelder, M. }\end{array}$ & 2015 & North America & Person-organization fit & Concept not central & Empirical & Individuals & Qualitative \\
\hline Gossett, C. & 2003 & North America & Person-organization fit & Concept not central & Empirical & Individuals & Quantitative \\
\hline $\begin{array}{l}\text { Gould-Williams, J. } \\
\text { Bottomley, P. } \\
\text { Redman, T. } \\
\text { Snape, E. } \\
\text { Bishop, D. } \\
\text { Limpatnitgul, T. } \\
\text { Mostafa, A. }\end{array}$ & 2014 & Europe & Person-organization fit & Concept not central & Empirical & Individuals & Quantitative \\
\hline Hatmaker, D. & 2015 & North America & Person-organization fit & As a process & Conceptual & & \\
\hline $\begin{array}{l}\text { Hatmaker, D. } \\
\text { Park, H. }\end{array}$ & 2014 & North America & Person-organization fit & Unclear & Empirical & $\begin{array}{l}\text { Individuals } \\
\text { (+ networks) }\end{array}$ & $\begin{array}{l}\text { Qualitative \& } \\
\text { quantitative }\end{array}$ \\
\hline $\begin{array}{l}\text { Hsiung, T. } \\
\text { Hsieh, A. }\end{array}$ & 2003 & Asia & Person-organization fit & Unclear & Empirical & $\begin{array}{l}\text { Individuals \& } \\
\text { organizations }\end{array}$ & Quantitative \\
\hline Jaskyte, K. & 2005 & North America & Person-organization fit & As a process & Empirical & $\begin{array}{l}\text { Individuals \& } \\
\text { organizations }\end{array}$ & Quantitative \\
\hline $\begin{array}{l}\text { Jaskyte, K. } \\
\text { Lee, M. }\end{array}$ & 2009 & North America & Person-organization fit & As a process & Empirical & $\begin{array}{l}\text { Individuals \& } \\
\text { organizations }\end{array}$ & Quantitative \\
\hline $\begin{array}{l}\text { Patti, R. } \\
\text { Austin, M. }\end{array}$ & 1978 & North America & Person-organization fit & Unclear & Conceptual & & \\
\hline
\end{tabular}




\begin{tabular}{|c|c|c|c|c|c|c|c|}
\hline $\begin{array}{l}\text { Peng, S. } \\
\text { Pandey, S. } \\
\text { Pandey, S. }\end{array}$ & 2015 & North America & Person-organization fit & Unclear & Empirical & $\begin{array}{l}\text { Individuals \& } \\
\text { organizations }\end{array}$ & Quantitative \\
\hline $\begin{array}{l}\text { Selden, S. } \\
\text { Sowa, J. }\end{array}$ & 2015 & North America & Person-organization fit & As a process & Empirical & $\begin{array}{l}\text { Individuals \& } \\
\text { organizations }\end{array}$ & $\begin{array}{l}\text { Qualitative \& } \\
\text { quantitative }\end{array}$ \\
\hline $\begin{array}{l}\text { Yankey, J. } \\
\text { Coulton, C. }\end{array}$ & 1979 & North America & Person-organization fit & Unclear & Conceptual & & \\
\hline $\begin{array}{l}\text { Benson-Rea, M. } \\
\text { Shore, C. }\end{array}$ & 2012 & $\begin{array}{l}\text { Supranational } \\
\text { institutions }\end{array}$ & Supranational socialization & As a process & Empirical & $\begin{array}{l}\text { Individuals \& } \\
\text { organizations }\end{array}$ & Qualitative \\
\hline Beyers, J. & 2010 & $\begin{array}{l}\text { Supranational } \\
\text { institutions }\end{array}$ & Supranational socialization & As a process & Conceptual & & \\
\hline $\begin{array}{l}\text { Eberlein, B. } \\
\text { Radaelli, C. }\end{array}$ & 2010 & $\begin{array}{l}\text { Supranational } \\
\text { institutions }\end{array}$ & Supranational socialization & Unclear & Conceptual & & \\
\hline $\begin{array}{l}\text { Garand, J., } \\
\text { Parkhurst, C. } \\
\text { Seoud, R. }\end{array}$ & 1991 & $\begin{array}{l}\text { Supranational } \\
\text { institutions }\end{array}$ & Supranational socialization & Org. affiliation & Empirical & Individuals & Quantitative \\
\hline $\begin{array}{l}\text { Haski-Leventhal, D. } \\
\text { Radaelli, C. }\end{array}$ & 2010 & $\begin{array}{l}\text { Supranational } \\
\text { institutions }\end{array}$ & Supranational socialization & Unclear & Conceptual & & \\
\hline Hooghe, L. & 1999 & $\begin{array}{l}\text { Supranational } \\
\text { institutions }\end{array}$ & Supranational socialization & Org. affiliation & Empirical & Individuals & $\begin{array}{l}\text { Qualitative \& } \\
\text { quantitative }\end{array}$ \\
\hline Irondelle, B. & 2003 & Europe & Supranational socialization & Unclear & Empirical & $\begin{array}{l}\text { Individuals \& } \\
\text { organizations }\end{array}$ & Qualitative \\
\hline $\begin{array}{l}\text { Juncos, A. } \\
\text { Pomorska, K. }\end{array}$ & 2011 & $\begin{array}{l}\text { Supranational } \\
\text { institutions }\end{array}$ & Supranational socialization & Org. affiliation & Empirical & $\begin{array}{l}\text { Individuals \& } \\
\text { organizations }\end{array}$ & $\begin{array}{l}\text { Qualitative \& } \\
\text { quantitative }\end{array}$ \\
\hline Kerremans, B. & 1996 & $\begin{array}{l}\text { Supranational } \\
\text { institutions }\end{array}$ & Supranational socialization & Unclear & Conceptual & & \\
\hline McCarthy, R. & 1997 & $\begin{array}{l}\text { Supranational } \\
\text { institutions }\end{array}$ & Supranational socialization & Org. affiliation & Empirical & Individuals & Qualitative \\
\hline $\begin{array}{l}\text { Murdoch, Z. } \\
\text { Geys, B. }\end{array}$ & 2012 & $\begin{array}{l}\text { Supranational } \\
\text { institutions }\end{array}$ & Supranational socialization & Unclear & Empirical & Individuals & $\begin{array}{l}\text { Qualitative \& } \\
\text { quantitative }\end{array}$ \\
\hline Niemann, A. & 2004 & $\begin{array}{l}\text { Supranational } \\
\text { institutions }\end{array}$ & Supranational socialization & Org. affiliation & Conceptual & & \\
\hline
\end{tabular}




\begin{tabular}{|c|c|c|c|c|c|c|c|}
\hline $\begin{array}{l}\text { Quaglia, L. } \\
\text { De Francesco, F. } \\
\text { Radaelli, C. }\end{array}$ & 2008 & $\begin{array}{l}\text { Supranational } \\
\text { institutions }\end{array}$ & Supranational socialization & Org. affiliation & Conceptual & & \\
\hline Saurruger, S. & 2013 & $\begin{array}{l}\text { Supranational } \\
\text { institutions }\end{array}$ & Supranational socialization & Unclear & Conceptual & & \\
\hline Smith, M.E. & 2000 & $\begin{array}{l}\text { Supranational } \\
\text { institutions }\end{array}$ & Supranational socialization & Org. affiliation & Conceptual & & \\
\hline Suvarierol, S. & 2011 & $\begin{array}{l}\text { Supranational } \\
\text { institutions }\end{array}$ & Supranational socialization & Org. affiliation & Empirical & Individuals & Qualitative \\
\hline $\begin{array}{l}\text { Suvarierol, S. } \\
\text { Bsuioc, M. } \\
\text { Groenleer, M. }\end{array}$ & 2013 & $\begin{array}{l}\text { Supranational } \\
\text { institutions }\end{array}$ & Supranational socialization & As a process & Empirical & $\begin{array}{l}\text { Individuals \& } \\
\text { organizations }\end{array}$ & $\begin{array}{l}\text { Qualitative \& } \\
\text { quantitative }\end{array}$ \\
\hline $\begin{array}{l}\text { Trondal, J. } \\
\text { Van Den Berg, C. } \\
\text { Suvarierol, S. }\end{array}$ & 2008 & $\begin{array}{l}\text { Supranational } \\
\text { institutions }\end{array}$ & Supranational socialization & Org. affiliation & Empirical & Individuals & $\begin{array}{l}\text { Qualitative \& } \\
\text { quantitative }\end{array}$ \\
\hline Davis, R. & 2011 & North America & Public Service Motivation & Org. affiliation & Empirical & Individuals & $\begin{array}{l}\text { Qualitative \& } \\
\text { quantitative }\end{array}$ \\
\hline Kjeldsen, A. & 2014 & Europe & Public service motivation & Org. affiliation & Empirical & Individuals & $\begin{array}{l}\text { Qualitative \& } \\
\text { quantitative }\end{array}$ \\
\hline $\begin{array}{l}\text { Kjeldsen, A. } \\
\text { Jacobsen, C. }\end{array}$ & 2013 & Europe & Public service motivation & Org. affiliation & Empirical & Individuals & Quantitative \\
\hline Perry, J. & 1997 & North America & Public service motivation & Org. affiliation & Empirical & Individuals & Quantitative \\
\hline Vandenabeele, W. & 2011 & Europe & Public service motivation & As a process & Empirical & Individuals & Quantitative \\
\hline $\begin{array}{l}\text { Waterhouse, J. } \\
\text { French, E. } \\
\text { Puchala, N. }\end{array}$ & 2014 & Oceania & Public service motivation & As a process & Empirical & Individuals & $\begin{array}{l}\text { Qualitative \& } \\
\text { Quantitative }\end{array}$ \\
\hline $\begin{array}{l}\text { Gidengil, E. } \\
\text { Vengroff, } R \text {. }\end{array}$ & 2008 & North America & Men/women differences & Unclear & Empirical & Individuals & Qualitative \\
\hline $\begin{array}{l}\text { Bhatta, G. } \\
\text { Washington, S. }\end{array}$ & 2003 & Oceania & Men/women differences & Concept not central & Empirical & Individuals & Quantitative \\
\hline $\begin{array}{l}\text { Rinfret, N. } \\
\text { Lortie-Lussier, M. }\end{array}$ & 1997 & North America & Men/women differences & Concept not central & Empirical & Individuals & Quantitative \\
\hline
\end{tabular}




\begin{tabular}{|c|c|c|c|c|c|c|c|}
\hline York, R. & 1988 & North America & Men/women differences & Unclear & Empirical & Individuals & Qualitative \\
\hline $\begin{array}{l}\text { Balle-Hansen, M. } \\
\text { Lauridsen, J. }\end{array}$ & 2004 & International & Other & Concept not central & Empirical & Individuals & Quantitative \\
\hline Bianculli, A. & 2013 & South America & Other & Concept not central & Empirical & $\begin{array}{l}\text { Organizations } \\
\text { (+ networks) }\end{array}$ & Qualitative \\
\hline Collins, N. & 1985 & Europe & Other & Unclear & Conceptual & & \\
\hline Davis, R. & 2013 & North America & Other & Org. affiliation & Empirical & Individuals & Quantitative \\
\hline Dolan, J. & 2002 & North America & Other & Org. affiliation & Empirical & $\begin{array}{l}\text { Individuals \& } \\
\text { organizations }\end{array}$ & Quantitative \\
\hline $\begin{array}{l}\text { Hatmaker, D. } \\
\text { Park, H. } \\
\text { Rethemeyer, R. }\end{array}$ & 2011 & North America & Other & As a process & Empirical & $\begin{array}{l}\text { Individuals } \\
\text { (+ networks) }\end{array}$ & $\begin{array}{l}\text { Qualitative \& } \\
\text { quantitative }\end{array}$ \\
\hline $\begin{array}{l}\text { Jackson, M. } \\
\text { Smith, R. }\end{array}$ & 1996 & Oceania & Other & Concept not central & Empirical & Individuals & $\begin{array}{l}\text { Qualitative \& } \\
\text { quantitative }\end{array}$ \\
\hline Kim, L. & 2005 & Asia & Other & Concept not central & Empirical & Individuals & Qualitative \\
\hline Oberfield, Z. & 2010 & North America & Other & As a process & Empirical & $\begin{array}{l}\text { Individuals \& } \\
\text { organizations }\end{array}$ & $\begin{array}{l}\text { Qualitative \& } \\
\text { quantitative }\end{array}$ \\
\hline Oberfield, Z. & 2012 & North America & Other & As a process & Empirical & Individuals & $\begin{array}{l}\text { Qualitative \& } \\
\text { quantitative }\end{array}$ \\
\hline Oberfield, $\mathrm{Z}$. & 2014 & North America & Other & As a process & Empirical & Individuals & $\begin{array}{l}\text { Qualitative \& } \\
\text { quantitative }\end{array}$ \\
\hline Smith, M.P. & 1976 & North America & Other & Unclear & Conceptual & & \\
\hline $\begin{array}{l}\text { Wilkins, V. } \\
\text { Williams, B. }\end{array}$ & 2008 & North America & Other & Unclear & Empirical & Organizations & Qualitative \\
\hline $\begin{array}{l}\text { Wilkins, V. } \\
\text { Williams, B. }\end{array}$ & 2009 & North America & Other & Unclear & Empirical & Organizations & $\begin{array}{l}\text { Qualitative \& } \\
\text { Quantitative }\end{array}$ \\
\hline
\end{tabular}

Figure 3. Results of the literature review $(n=58)$ 


\begin{abstract}
' Socialization is also an uninterrupted process of adjustment. For example, organizational members are continuously influenced by their training, their coworkers, their understanding of the job, as well as the prospects of their organization (Taormina, 1997). However, in this article, we focus on the socialization of newcomers to a position and/or to an organization.
\end{abstract}

ii As suggested by the results of the present review, there is another reason that can explain the quasi absence of PA research in existing reviews on organizational socialization: most PA research on organizational socialization is relatively recent.

iii http://www.prisma-statement.org.

iv The 'Public Administration' subject area of the Web of Science contained the 47 following journals in 2015: Administration \& Society, American Review of Public Administration, Amme Idaresi Dergisi, Australian Journal of Public Administration, Canadian Public Administration, Canadian Public Policy, Civil Szemle, Climate Policy, Contemporary Economic Policy, Environment and Planning C - Government and Policy, Gestion Y Politica Publica, Governance - An International Journal of Policy Administration and Institutions, Human Service Organizations Management Leadership \& Governance, International Public Management Journal, International Review of Administrative Sciences, Journal of Accounting and Public Policy, Journal of Comparative Policy Analysis, Journal of European Public Policy, Journal of European Social Policy, Journal of Homeland Security and Emergency Management, Journal of Policy Analysis and Management, Journal of Public Administration Research and Theory, Journal of Public Policy, Journal of Social Policy, Lex Localis - Journal of Local Self-Government, Local Government Studies, Nonprofit Management \& Leadership, Policy and Politics, Policy and Society, Policy Sciences, Policy Studies, Policy Studies Journal, Public Administration, Public Administration and Development, Public Administration Review, Public Management Review, Public Money \& Management, Public Performance \& Management Review, Public Personnel Management, Public Policy and Administration, Regulation \& Governance, Review of Policy Research, Review of Public Personnel Administration, Revista Del Clad Reforma Y democracia, Science and Public Policy, Social Policy \& Administration, Transylvanian Review of Administration Sciences.

$\checkmark$ There is a multitude of PA articles documenting the adjustment between individuals and their public organization. For example, there are streams of research focused on the training of public officials or on the way street-level bureaucrats deal with their discretion power (e.g., Kaufman's study on forest rangers: Tipple \& Wellman, 1991). Our list of keywords does not cover all those articles on 'socialization' in general. However, in the literature, the use and definition of 'organizational socialization' as a process of mutual adjustment between an organization and its new members are well established. Based on this observation, we designed a list of keywords and cleaned our sample of articles to focus on those which use the concept of organizational socialization and refer to it in this way.

vi Wilkins and Williams $(2008,2009)$ look at the effect of organizational socialization on police officers' racial profiling. Their results are discussed in the next section.

vii The 10 last articles of our sample fitted with our selection criteria and provided insights into the process of adjustment between an organization and its members. However, they did not use the word 'socialization' or too occasionally (e.g., 1 or 2 times) to consider that it is a 'central' concept. We distinguish those 10 articles from the others because it should not be surprising if they do not introduce an elaborated operationalization of the 'socialization' concept.

viii We used the institutional affiliation of the first author for six articles: those articles are purely conceptual or they are empirical but the country of the examined organization(s) has been anonymized. 